J. Clin. Chem. Clin. Biochem.

Vol. 14, 1976, pp. 433-435

\title{
A Spectrophotometric Method for the Determination of Monoglyceride Hydrolase
}

\author{
Von W. Hansen
}

\section{Medizinische Klinik der Technischen Universität, München}

(Received January 8/May 10, 1976)

Summary: A monoglyceride hydrolase assay is introduced in which the activity of the enzyme is determined by the use of coupled enzymatic reactions. Measurements are easy to perform on a conventional photometer; they are specific, precise and show good reproducibility.

\section{Eine photometrische Methode zur Bestimmung der Monoglyceridhydrolase}

Zusammenfassung: Eine Methode zur Bestimmung der Monoglyceridhydrolase im zusammengesetzten enzymatischen Test wird vorgestellt. Die Messungen lassen sich in einfacher Weise mit dem Photometer durchfuhren. Sie sind spezifisch, präzise und gut reproduzierbar.

\section{Introduction}

Monoglyceride hydrolase ${ }^{1}$ ) can be detected in plasma at low activity (1). After the administration of heparin, the enzyme activity increases (2). Monoglyceride hydrolase has found interest as a key enzyme in the metabolism of plasma triglycerides as well as a diagnostic tool for assessing the function of the liver $(1,3-5)$.

The activity of monoglyceride hydrolase can be determined either by the fatty acids or by the glycerol liberated over a certain time from a monoglyceride substrate $(1,2,5-8)$. In the following paper a new method is introduced. It is based upon the determination of glycerol. The concept differs from the conventional assays in so far as measurement is achieved by coupled enzymatic reactions. Thus, the reaction can be followed continuously on a recording spectrophotometer. Preliminary results were encouraging, al though determinations had to be performed at a low substrate concentration (4). Meanwhile the assay has been improved. A substrate has been found which allows measurements under optimal conditions. As will be seen the test is now easy and rapid. The results show good reproducibility.

1) Enzymes: monoglyceride hydrolase = glycerol ester hydrolase (EC 3.1.1.3); glycerol kinase = ATP: glycerol phosphotransferase (EC 2.7.1.30); pyruvate kinase = ATP: pyruvate phosphotransferase (EC 2.7.1.40); lactate dehydrogenase $=L$-lactate: NAD oxidoreductase (EC 1.1.1.27).

\section{Methods}

The monoglyceride hydrolase assay is based on the following reactions:

(1) glycerol monooleate $\stackrel{\text { monoglyceride hydrolase }}{\longrightarrow}$ glycerol + oleate

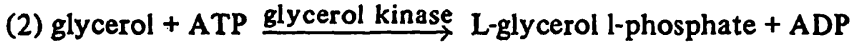

(3) ADP + phospoenolypruvate pyruvate kinase $\mathrm{ATP}+$ pyruvate

(4) pyruvate $+\mathrm{NADH}+\mathrm{H}^{+} \stackrel{\text { lactate dehydrogenase }}{\longrightarrow}$ lactate $+\mathrm{NAD}^{+}$

The reaction catalyzed by monoglyceride hydrolase is coupled with the oxidation of NADH, which can be followed spectrophotometrically at $334 \mathrm{~nm}$. Equations (2)-(4) were suggested first by Garland \& Randle (9) and Kreutz (10). The main problems are posed by glycerol monooleate and oleate because they are practically insoluble in water. It therefore was necessary to solubilize the monoglyceride with taurodeoxycholic acid. This has the advantage of yielding a well defined and clear solution which can be penetrated by the photometer light beam. Albumin was added to bind the free fatty acids.

For practical purposes 3 solutions were prepared: "buffer", "reaction mixture" and "substrate". The "buffer" was made to contain $100 \mathrm{mmol} / 1$ triethanolamine and $4 \mathrm{mmol} / \mathrm{MgSO}_{4}$; the $\mathrm{pH}$ was adjusted to 7.6. For the preparation of the "reaction mixture", $250 \mathrm{mg}$ bovine albumin (puriss. quality, Behringwerke, Marburg, Germany) were first dissolved in $9 \mathrm{ml}$ "buffer" by the use of a magnetic stirrer. Then the following compounds (all from Boehringer, Mannheim, Germany) were added and dissolved by stirring gently: NADH $(0.4 \mathrm{mmol} / \mathrm{l})$, ATP $(2.2 \mathrm{mmol} / \mathrm{l})$; phosphoenolpyruvate $(0.73 \mathrm{mmol} / \mathrm{l})$; lactate dehydrogenase ( $50 \mathrm{U}$ or $0.2 \mathrm{mg})$; pyruvate kinase ( $20 \mathrm{U}$ or $0.1 \mathrm{mg}$ ); glycerol kinase (17 U or $0.2 \mathrm{mg}$ ). The "substrate" was made up from $10 \mathrm{ml}$ "buffer", $1 \mathrm{~g}$ taurodeoxycholic acid and $100 \mathrm{mg}$ glycerol monooleate (both from Calbiochem, San Diego, California). The monoglyceride was purified before use in order to eliminate traces of free glycerol and free fatty acids: $1 \mathrm{~g}$ was dissolved in $250 \mathrm{ml}$ petroleum benzene (boiling range 
$60-80^{\circ} \mathrm{C}$ )-ethyl acetate $(200 \mathrm{ml}+100 \mathrm{ml})$; after washing 3 times with $25 \mathrm{ml}$ of distilled water the lower phase was separated and evaporated under vacuum; the remaining monoglyceride was stored at $4^{\circ} \mathrm{C}$ under $\mathrm{N}_{2}$. Complete solubilization of glycerol monooleate was achieved by sonification of the substrate for $60 \mathrm{~s}$, setting $60 \mathrm{~W}$, temperature $4^{\circ} \mathrm{C}$ (Braunsonic, Braun, Melsungen, Germany). The micellar solution was kept at $4^{\circ} \mathrm{C}$. It was stable for at least 1 week. If not listed otherwise all chemicals were obtained from Merck, Darmstadt, Germany.

Blood samples were collected in heparinized tubes and kept at $4^{\circ} \mathrm{C}$. After centrifugation they were either used immediately or frozen for subsequent assay. There was no decline of activity within 2 weeks.

For the determination of monoglyceride hydrolase microcuvettes were employed (light path $1 \mathrm{~cm}$ ). $50 \mu \mathrm{l}$ sample or $50 \mu \mathrm{l}$ saline (for blank value) were added to $400 \mu \mathrm{l}$ "reaction mixture" and $100 \mu \mathrm{l}$ "substrate". The reaction was followed in a photometer with recording attachments (Eppendorf Gerätebau, Hamburg, Germany). The wave length was $334 \mathrm{~nm}$, the temperature was kept at $25^{\circ} \mathrm{C}$, the paper speed was $1 \mathrm{~cm} / \mathrm{min}$. All determinations were in duplicate. Enzyme activity was calculated from the absorption curve. After $3 \mathrm{~min}$ preincubation the reaction followed almost zero order kinetics. The angle was measured. If necessary correction for the blank value was made by subtracting the tg of both angles. Calculation was done according to the following formula:

Enzyme activity $=\operatorname{tg} \alpha \times \frac{V \times 1000 \times \dot{p}}{V \times \epsilon \times P} \quad(U / 1)$

( $\alpha=$ angle of absorbance curve; $v=$ sample volume; $V=$ total volume; $\epsilon=$ absorption coefficient of NADH; $p=$ paper speed; $\mathrm{P}=$ diameter of the registration scale at absorbance $=1.0=20 \mathrm{~cm}$ )

Postheparin plasma samples usually required dilution with saline by $1: 5$. Under this condition monoglyceride hydrolase activity was $458 \times \operatorname{tg} \alpha$.

For comparison monoglyceride hydrolase was also determined by another method which has been published elsewhere (4). In this method glycerol monopalmitate (puriss. quality, Roth, Karlsruhe) is used as a substrate.

Statistical calculations and Lineweaver-Burk plots were performed on a Hewlett-Packard 9830 A computer with printing attachments.

\section{Results and Discussion}

Initially the monoglyceride hydrolase reaction is accompanied by a fast decrease in absorption. This is due to free glycerol present in the plasma sample. After about $3 \mathrm{~min}$ of "preincubation" free glycerol is metabolized and the effect of monoglyceride hydrolase becomes visible from a slower continuous decrease in absorption. In order to avoid disturbances from glycerol, plasma samples should be small (less than $10 \%$ of the total volume) and reagents should be essentially free of glycerol. The monoglyceride hydrolase reaction was not influenced by physostigmin $(10 \mathrm{mg} / \mathrm{l})$ which inhibits esterases.

The relationship between enzyme concentration and enzyme activity was linear over a wide range (fig. 1). The absorbance angle was between $10^{\circ}$ and $50^{\circ}$. Measurement should be performed in this range. Samples with high monoglyceride hydrolase activity may require dilution with saline.

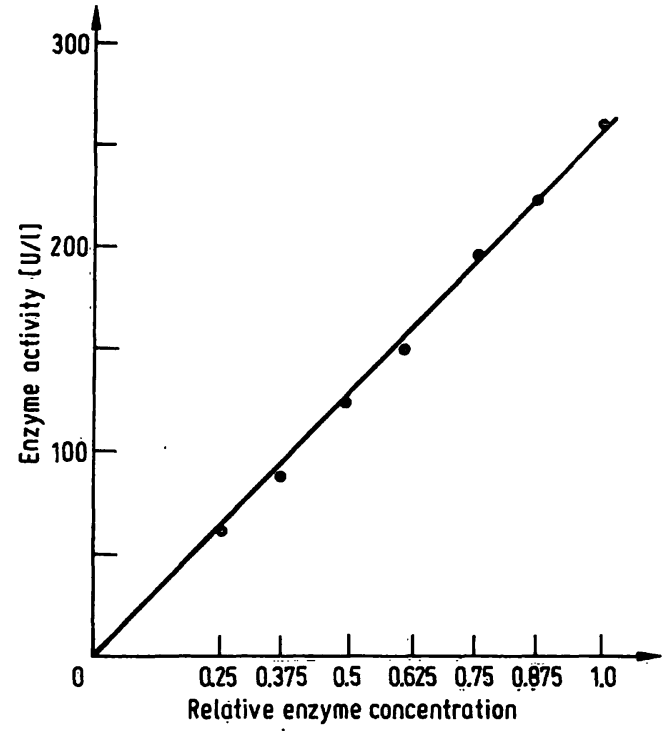

Fig. 1. Relationship between enzyme concentration and enzyme activity (calibration curve). The various enzyme concentrations were adjusted by diluting a plasma sample (1.0) with saline.

In order to find optimal conditions of measurement various substrates were tested in the same sample. Results from a typical experiment are given in figure 2 . Variations in the substrate concentration had only little effect upon enzyme activity beyond $4 \mathrm{mmol} / \mathrm{l}$ glycerol monooleate. For the monoglyceride hydrolase assay a concentration of $5 \mathrm{mmol} / \mathrm{l}$ glycerol monooleate was chosen.

In order to establish the acourancy of the monoglyceride hydrolase test in 72 samples, measurements were also carried out with another method (4). In this method glycerol monopalmitate is used as a substrate. The results obtained with this method were lower by a factor of 9.7 .



Fig. 2. Relationship between substrate concentrations and monoglyceride hydrolase activity. The concentration of taurodeoxycholic acid was kept constant. In this experiment $K_{\mathrm{m}}$ was $0.98 \mathrm{mmol} / 1 ; \mathrm{V}$ was $512 \mathrm{U} / 1$. 
This is probably due to the low substrate concentration $(0.3 \mathrm{mmol} / 1)$. The correlation of measurements, however, was good $(r=0.971)$.

20 samples from one patient were tested the same day and 15 samples from another patient on different days with newly prepared substrates. In both instances the coefficient of variation was $3 \%(\overline{\mathrm{x}} \pm \mathrm{s}: 365.6 \pm 14.4 \mathrm{U} / 1$ and $334.4 \pm 12.9 \mathrm{U} / 1)$. This is in agreement with the results obtained by Fritsch \& Rick using a titrimetric procedure (6). In the method used for comparison the coefficient of variation in measurements on different days was $5.5 \%$ (4). This is probably due to the substrate, which is difficult to handle and which does not allow measurements at optimal conditions.

The effect of heparin upon monoglyceride hydrolase in plasma was investigated in 8 healthy male volunteers (fig. 3). Shortly after the injection, enzyme activity rose and reached a maximum after 7 to $10 \mathrm{~min}$. Then there was a gradual decline.

It has been shown by Benzonana \& Desnuelle for pancreatic lipase that the activity of enzymes acting upon a water-insoluble substrate is not so much a function of the substrate concentration but of the "lipid / water interface concentration", that is the interfacial area. in a volume unit of emulsion (11). An advantage of the monoglyceride hydrolase assay may be seen in its well defined micellar substrate (12). Variations of particle

\section{References}

1. Greten, H., Levi, R. I. \& Fredrickson, D. S. (1969). J. Lipid Res. 10 326-330.

2. Shore, B. \& Shore, V. (1961). Am. J. Physiol. 201, 915-922.

3. Glueck, C. J., Levi, R. I. \& Fredrickson, D. S. (1971). Ann. Intern. Med. 75, 345-352.

4. Hansen, W. (1975). Klin. Wochenschr. 53, 135-137.

5. Hansen, W. (1976). Med. Klin. 71, 286-287.

6. Fritsch, W.-P. \& Rick, W. (1974), in Methoden der enzymatischen Analyse (Bergmeyer, H. U., Hrsg.) 3. Aufl., Bd. I, 858-861, Verilag Chemie, Weinheim/Bergstr.

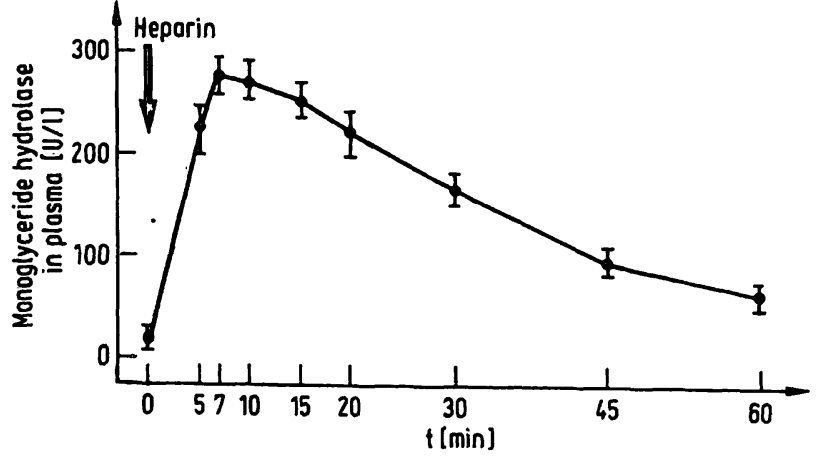

Fig. 3. Monoglyceride hydrolase in plasma after administration of heparin. Heparin (Thrombophob, Nordmark-Werke, Hamburg, Germany) was given intravenously to 8 healthy, male volunteers after an overnight fast. The dose was $10 \mathrm{U} / \mathrm{kg}$ body weight. Blood was drawn from an indwelling needle at constant time-intervals before and after the administration of heparin and collected in heparinized tubes. Results are given as $\bar{x} \pm s_{\bar{x}}$.

size in conventional fat emulsions which result in unpredictable variations in "interface concentration" do not have to be taken into account.

\section{Acknowledgements}

Hannelore Bolle is thanked for her expert technical assistance. Dr. rer. nat. F. L. Goldmann gave helpful technical advice. This work was supported by Deutsche Forschungsgemeinschaft (Ha 596/2).
7. Biale, Y. \& Shafrir, E. (1969). Clin. Chim. Acta 23, 413-419.

8. Arons, D. L., Schreibman, P. H. \& Arky, R. A. (1971).

Proc. Soc. Exp. Biol. Med. 137, 780-782.

9. Garland, P. B. \& Randle, P. I. (1962). Nature 190, 987-988.

10. Kreutz, F. (1962). Klin. Wochenschr. 40, 362-365.

11. Benzonana, G. \& Desnuelle, P. (1965). Biochim. Biophys. Acta $105,121-136$.

12. Carey, M. C. \& Small, D. M. (1970). Am. J. Med. 49, 590-608.
Priv.-Doz. Dr. Werner Hansen 2. Medizinische Klinik der TU München Ismaninger Straße 22

D-8000 München 80 
